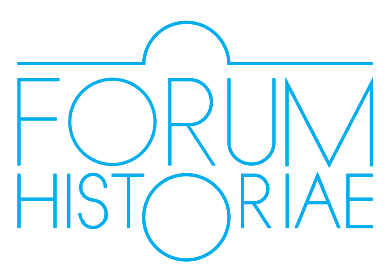

\title{
Stratégia vytvárania národoveckých elít v najznámejšom slovenskom spolku*
}

\author{
Rastislav Molda
}

\begin{abstract}
MOLDA, Rastislav: The Strategy of Forming a Nationalist Elite in the Best-Known Slovak Association.

The study, The Strategy of Forming a Nationalist Elite in the Best-Known Slovak Association, discusses the issue of establishing a new Slovak nationalist elite in the so called "matica" years. In the first chapter, a theoretical background is provided which seeks to define the term "elite" for the needs of this study on the basis of contemporary literature and especially sociology. The second part is analytical and can be divided into two subparts.

In the first, members of the association and its management are identified, including who was responsible for the decision to grant scholarships. The article focuses on whether the nationalists associated in Matica considered themselves to be the elite of Slovak society.

A more thorough identification of the social and professional background of the committee members is the basis of the second subpart. Here, a detailed analysis of the strategies used by the association's management to create new generations of nationalist elites is provided. This primarily concerns the process of granting scholarships to students, specifically law students. They could receive financial support if certain criteria were met, or due to references from older, established nationalists. This offered the possibility to complete their studies, thus providing job opportunities, the beginning of a career and subsequent entry into the elite of the civil society that was being formed.

The study also discusses if graduates entered the nationalist elite, how successful they were and whether they managed to establish themselves within society. The question of how beneficial the investment in them was shall be answered from the perspective of the national movement development.

Keywords: elites, national movement, Matica slovenská, associations, scholarship
\end{abstract}

$\mathrm{D}$ ruhá polovica „dlhého“ 19. storočia je obdobím, ked’ habsburská monarchia a súčasne aj Uhorsko zaznamenali značný civilizačný pokrok. Bolo to obdobie pomerne zásadných zmien spojených s modernizáciou. Tie sa uskutočnili v spoločensko-politickej oblasti (dochádzalo k postupnej premene uhorskej stavovskej spoločnosti na občiansku) a v ekonomickej oblasti (naštartovala sa premena feudalizmu na trhové hospodárstvo). Dôsledkom týchto zmien bol aj vznik nových spoločenských vrstiev, zamestnaneckých štruktúr a elít spoločnosti. Ak chceme bližšie spoznat' túto problematiku, musíme rozumiet' dobovému kontextu v jeho najkomplikovanejších sociálnych a politických aspektoch. ${ }^{1} \mathrm{~V}$ tomto období dochádzalo aj k zmene životného štýlu jednotlivých vrstiev spoločnosti, ktoré sa aktívne zúčastňovali na verejnom i spolkovom živote. ${ }^{2} \mathrm{~V}$ druhej polovici 19. storočia bol o spolky eminentný záujem a tie dokázali ovplyvnit' viaceré sféry l'udského života. ${ }^{3}$ Dopyt po spolkovom živote odzrkadluje

\footnotetext{
* Túto prácu podporila Agentúra na podporu výskumu a vývoja na základe zmluvy č. APVV-14-0644 Kontinuitya diskontinuity politických a spoločenských elít na Slovensku v 19. a 20. storočí.

1 Podrobnejšie o týchto zmenách napr.: HOLEC, Roman. Osobnost' a región (metodologické úvahy). In PEKÁR, Martin - DERFIŇÁK, Patrik (eds.). Regionálne dejiny a dejiny regiónov. Prešov : Univerzum, 2004, s. 39.

2 DZURIKANINOVÁ. Nikoleta. Stanovy ako prameň k činnosti spolkov v období dualizmu (príklad mesta Košice). In Kultúrne dejiny, 2015, roč. 6, č. 1, s. 65-86.

3 MANNOVÁ, Elena. Ideové smery, kultúrny a spoločenský život. In KOVÁČ, Dušan a kol. Slovenskom v 20. storočí. I. Na začiatku storočia 1901 - 1914. Bratislava : Veda, 2004, s. 249 a n.
} 
aj nárast počtu spolkov, v roku 1862 ich bolo v Uhorsku evidovaných 579 a v roku 1878 už 3 995. ${ }^{4}$ Z celej plejády spolkov má ten, ktorý vznikol v roku 1863 a nazvaný bol „Slovenská Mati$c a$ ", v slovenskom národnom príbehu výnimočné postavenie. Do tradície vošiel ako spolok národného i konfesionálneho zjednotenia Slovákov. Má miesto vo všetkých učebniciach dejepisu slovenskej proveniencie ( $v$ tých, ktoré približujú toto obdobie), čím sa výrazne zapísal do historickej pamäti. Aj napriek tomu, že jeho dejiny už vyšli vo viacerých knižných spracovaniach, ${ }^{5}$ súčasná historiografia presnejšie nepozná jeho sociálnu a konfesionálnu štruktúru, regionálne rozloženie a ani osobnosti, ktoré sa aktívne i pasívne podielali na jeho rozvoji a činnosti.

Cielom štúdie je pokúsit’ sa, na základe priblíženia sociálneho zloženia spolku, odpovedat' na nasledujúce otázky: Dokázali sa v jeho vedení etablovat’ elitné vrstvy slovenskej, národne uvedomelej a angažujúcej sa spoločnosti, v tomto prípade národovecké elity? Aké stratégie sa využívali v spolku na vytváranie nových generácií národoveckých elít? V prvej časti sa snažím o bližšie spoznanie sociálneho a regionálneho zloženia členov spolku a jeho vedenia. Súčasne je možné preskúmat' platnost' niektorých dlhodobo akceptovaných a tradovaných téz o dejinách spolku, ktorý sa označuje adjektívom „národný“. Podl'a dodnes slovenskou historiografiou zachovaného hodnotenia išlo o: „najstaršiu vedeckú a kultúrnu ustanovizeň na Slovensku. [...] Matica ako prvá národná ustanovizeň [...] “6 Inú klasifikáciu v slovenskom vedeckom prostredí nájdeme iba zriedka. Preto priblíženie regionálnej a sociálnej skladby „Slovenskej Matice“ môže tieto závery doplnit' a ponúknut širší pohlad na dejiny spolku. Objasnenie sociálnej štruktúry členov spolku zároveň poodhalí aj sociálnu skladbu národne uvedomelej a angažujúcej sa slovenskej spoločnosti.

V druhej časti štúdie sa snažím bližšie spoznat’ stratégie osôb vo vedení spolku pri vytváraní vlastných a lojálnych národoveckých elít. Skúmam, aké mechanizmy výberu, doplňovania a reprodukovania elít spomedzi spoločensky nižšie postaveného obyvatel'stva sa v samotnom spolku uplatňovali. Išlo predovšetkým o proces rozdelovania štipendií, ktoré mali novej generácii zaistit’ prístup ku vzdelaniu. To bolo v modernej dobe jedným z prostriedkov vzostupu a cirkulácie elít. ${ }^{7}$ Skúmam, ktorí študenti boli podporení, ako prebiehal proces výberu a sledujem, či a ako sa neskôr dokázali etablovat'v komunite národovcov. Zaujíma ma, kol'kí zo študentov, ktorí získali štipendium, boli aktívni aj v samotnom spolku. Všímam si ich

4 MANNOVÁ, Elena. Prehlad vývoja spolkového hnutia na Slovensku z aspektu formovania občianskej spoločnosti. In STENA, Ján (ed.). Občianska spoločnost'. Problémy a perspektívy v ČSFR. Bratislava : Sociologický ústav SAV, 1991, s. 73.

5 BOTTO, Július. Dejiny Matice slovenskej 1863 - 1875. Martin : Matica slovenská, 1923, 237 s.; MRÁZ, Andrej. Matica slovenská v rokoch 1863 - 1875. Martin : Matica slovenská, 1935, 115 s.; HOLOTÍK L'udovít (ed.). Matica slovenská v našich dejinách. Bratislava : Vydavatel'stvo SAV, 1963, 431 s.; ELIÁŠs, Michal - WINKLER. Tomáš. Matica slovenská. Dejiny a prítomnost'. Martin : Matica slovenská, 2003, 496 s.; SEDLÁK, Imrich (ed.). Matica slovenská v národných dejinách. Martin: Matica slovenská, 2013, 496 s.;

6 ELIÁŠ - WINKLER 2003, s. 9.

7 Pozri viac: SVÁTEK, František. Politické elity v historiografii a politologii: náčrt problematiky a ideologie - slova - pojmu elity. In KOUTSKÁ, Ivana - SVÁTEK, František (eds.). Politické elity v Československu 1918 - 1948. Praha : Ústav pro soudobé dějiny AV ČR, 1994, s. 47. 
sociálny pôvod i to, či sa dokázali etablovat’ v iných/nových sociálnych vrstvách. Podporení študenti mali vytvorit' d'alšie generácie národoveckých elít, a preto v práci sledujem, nakol'ko sa tento proces uskutočnil v prospech slovenského nacionalizmu.

\section{Problematika teoretického vymedzenia a definície pojmu elita. Elity v dru- hej polovici 19. storočia}

Výskumu elít spoločnosti sa už dlhodobejšie venuje okrem sociológie a politológie aj historiografia. Existuje tak nielen v anglosaskom prostredí, v západnej Európe, ale aj v okolitých krajinách viacero, pre slovenských bádatelov zaujímavých a podnetných kníh i štúdií. Inšpiratívne sú z metodologického i analytického hl'adiska. ${ }^{8}$ Avšak absentuje všeobecne platná definícia elít, čo sa zretel'ne prenáša do slovenského kontextu. ${ }^{9}$ Vymedzenie elít spoločnosti možno pokladat' za jeden zo základných problémov tejto témy. Ani v súčasnej odbornej, predovšetkým sociologickej literatúre nepanuje jednoznačný konsenzus, pretože nie je možné definovat' konkrétne vlastnosti, znaky, atribúty a kvality, ktorými sa elity vyznačujú v rozdielnych spoločenských a politických podmienkach sveta. ${ }^{10}$ Avšak podla historika Františka Svátka k užitočnosti pojmu elít v historiografii je možné konštatovat', že presah tohto pojmu/konceptu zo sociológie a politológie do historiografie sa už v niektorých krajinách osvedčil. Podla Svátka je tiež dôležité, ako budeme pojem elity chápat’ a ako ho budeme v historickom výklade používat'.11

Elity v tejto štúdii chápeme v zmysle sociologického definovania ${ }^{12}$ ako l'udí s určitým - vyšším stupňom vzdelania, ktoré ich predurčuje na výkon určitej funkcie, na základe ktorej sú v istých súvislostiach držitel'mi moci a dokážu ovplyvňovat' ostatných. Na základe svojej funkcie získali sociálny a finančný kapitál, ktorý posilnil ich spoločenské postavenie. Elity chápeme ako l’udí, ktorí sú schopní sami vykonávat’ závažné rozhodnutia dotýkajúce sa samotného charakteru spoločnosti. ${ }^{13}$ Súčasne sa od zvyšku spoločnosti čiastočne izolujú, pretože majú rozdielny spôsob života. ${ }^{14}$ Bližšie poznanie elít, predovšetkým toho, akým spôsobom utvárajú, udržiavajú, prípadne obnovujú svoje mocenské postavenie, je dôležité aj na spoznanie spoločenských zmien. V tejto súvislosti je tiež zaujímavé zistit', aké podmienky mala konkrétna spoločnost’

8 Z viacerých monografií a štúdií vyberáme nasledovné: RISHEL, Joseph. Founding Families of Pittsburgh. The Evolution of a regional elite 1760 - 1910. Pittsburgh : University of Pittsburgh, 1900; BEST, Heinrich - GEBAUER Roland - SALHEISER Alex (eds). Elites and Social Change. Hamburg : Krämer, 2009; KUBÜ, Eduard - ŠOUŠA, Jiří (eds.). Finanční elity v českých zemích (Československu) 19. a 20. století. Praha : Dokořán, 2008; KOUTSKÁ, Ivana - SVÁTEK, František (eds.). Politické elity v Československu 1918 - 1948. Praha : Ústav pro soudobé dějiny AV ČR, 1994.

9 Zo slovenskej historiografie možno spomenút’ nasledujúcu monografiu analyzujúcu genealogické vzt’ahy mestskej elity v Trenčíne v 17. storočí : BRINDZA, Peter. Trenčianska mestská elita a jej genealogické väzby v storočí stavovských povstaní. Stropkov; Trenčín Lysá pod Makytou : Slovenská spoločnost' : Peter Brindza, 2015.

10 KELLER, Jan. Tři sociální světy. Praha: Slon - Sociologické nakladatelství, 2012, s. 64-69.

11 SVÁTEK, František. Elity v Československu 1918 - 1948? In KOUTSKÁ, Ivana - SVÁTEK, František (eds.). Politické elity $v$ Československu 1918 - 1948. Praha : Ústav pro soudobé dějiny AV ČR, 1994, s. 8.

12 Pozri viac: PECKA, Emanuel. Sociologické teórie elity. In KOUTSKÁ, Ivana - SVÁTEK, František (eds.). Politické elity v Československu 1918 - 1948. Praha : Ústav pro soudobé dějiny AV ČR, 1994, s. 13.

13 PECKA 1994, s. 13.

14 KELLER 2012, s. 62. 
pre rozvoj talentovaných l'udí, luudí s mimoriadnymi schopnost’ami, d’alej aké v nej boli predpoklady na ich uplatnenie. ${ }^{15}$

„Dlhé“ 19. storočie je pre výskum elít zaujímavým obdobím. V tomto storočí sa postupne rozpadalo relatívne neprerušované postavenie starej šlachtickej elity, tej ktorá bola v určitých sférach držitel'kou moci, autority, vplyvu a financií a ktorá mala toto postavenie po dlhé generácie. Svoj status opierala o rozsiahle majetky a monopolné privilégium v zastávaní vysokých štátnych, stoličných a cirkevných úradov. Proces modernizácie a centralizácie symbolizovaný panovníkom Jozefom II. mal za následok novú stratifikáciu spoločnosti a kreovanie nových funkčných elít - honorácie. Formujúce sa národné hnutia priniesli so svojimi členmi d’alších ašpirantov na status elity so snahou získat’ politický vplyv. Po revolučných udalostiach nastala v týchto oblastiach pomerne zásadná zmena, ktorá bola dôsledkom hladania lojálnych ludí voči panovníckemu dvoru, a tak sa napríklad k vyšším župným i cirkevným úradom na určitý čas dostávali l'udia, ktorí nemali šlachtický pôvod. V slovenskej spoločnosti je učebnicovo známy príklad Štefana Moyzesa a Jána Francisciho, ktorí ako nešlachtici zastávali vysoký cirkevný a župný úrad.

Predstavitelia slovenského národného hnutia združení v spolku „Slovenská Matica“ boli podporovaní (aktívne i pasívne) národne angažovaným slovenským obyvatel'stvom, ktorým boli vnímaní ako isté elitné kruhy, a taktiež ašpirovali na moc aj v rámci mocenskej štruktúry Uhorska. Zameriam sa na spoznanie stratégií slovenského národného hnutia pri podpore d’alších národovcov - na utváranie nových národných elít. Ked’že v Uhorsku bola sociálna mobilita smerom nahor, predovšetkým v snahe zastávat’ štátne úrady, častokrát spojená s asimiláciou s mad’arským jazykovým a kultúrnym prostredím, zaujímam sa o to, do akej miery sa podporení jednotlivci stotožnili s ideami slovenského nacionalizmu a nakol'ko podl'ahli dominantnému a v mnohých prípadoch aj prítažlivejšiemu mad’arsko-uhorskému nacionalizmu.

Dôležité je vediet', či sa samotní predstavitelia slovenského národného hnutia v 60. rokoch 19. storočia pokladali za elitné vrstvy slovenskej, národne uvedomelej a angažujúcej sa spoločnosti. 0 tom, že tomu tak bolo, svedčí tablo vybraných predstavitelov národného hnutia nazvané „Slovenskí výtečníci“. Tablo predstavovalo dôležitú pomôcku na vytvorenie bližšieho vzt’ahu, možno povedat’ až osobného puta medzi národovcom a „národom“. ${ }^{16}$ Podl'a dobového významu bol výtečník výraz pre vynikajúceho a znamenitého človeka - tablo vybraných predstavitelov národného hnutia teda predstavovalo výkvet z národovcov. Etymológia slová výtečník, vychádzajúc zo Svátka, je nasledujúca: ide pravdepodobne o originálny český výtvor, ktorý sa objavil v českej tlači ${ }^{17}$ už v polovici 40. rokov 19. storočia a neskôr sa s ním stretávame aj v korešpondencii Františka Ladislava Riegera i v náučnom slovníku, ktorého vydanie Rieger podporoval. Výtečník je zrejme prekladom či prevodom slova élite do češtiny. ${ }^{18}$ Odtial' sa termín rozšíril aj do slovenského prostredia.

15 PECKA 1994, s. 13.

16 KODAJOVÁ, Daniela. Národné oslavy a slávnosti ako prezentácia nacionalizmu. Úvod. In KUŠNIRÁKOVÁ, Ingrid a kol. „Vyjdeme v noci vo faklovom sprievode a rozsvietime svet“. Bratislava : Historický ústav SAV, 2012 , s. 70.

17 RIEGER, František Ladislav. Pohřeb Jana Pernera. In Květy, 1845, roč. 12, č. 111, s. 442-443.

18 SVÁTEK 1994, Politické elity v historiografii a politologii, s. 59. 


\section{Sociálne a regionálne zloženie Matice a jej vedenia}

Druhá polovica 19. storočia postavila slovenský nacionalizmus pred nové výzvy, akou bola agitácia a následné zapojenie čo najširších spoločenských vrstiev do činnosti národného hnutia, ktoré by sa inak zmenilo na neefektívny diskusný klub úzkej vrstvy inteligencie. Na spolkovej platforme Matice sa čiastočne zjednotilo úsilie memorandistov a Novej školy slovenskej aj napriek tomu, že sa v principiálnom nazeraní na koncepciu slovenskej politiky ich pohlady zásadne líšili. ${ }^{19}$

Povolenie činnosti spolku sprevádzalo všeobecné nadšenie. Elán v slovenskom národnom hnutí podnecoval aj mediálny diskurz. Viaceré periodiká slovenskej proveniencie podrobne informovali o vznikajúcom spolku a vyzývali národovcov, aby doň vstúpili. Najväčšiu pozornost' formujúci sa spolok dostal v Pešt'budínskych vedomostiach. Na prvom valnom zhromaždení bolo podla zápisnice prítomných 541 účastníkov. Podla oficiálnych spolkových zápisníc z piatich rokov, z ktorých sú údaje k dispozícii, to bol najvyšší počet. V roku 1865 bolo prítomných 396 l'udí, v nasledujúcom roku ich bolo 165, v roku 1867 sa v Turčianskom Sv. Martine do prezenčnej listiny zapísalo 206 osôb a v roku 1868 bolo na zhromaždení prítomných 258 členov. ${ }^{20}$ Z d’alších rokov už údaje absentujú. Ustanovujúce zhromaždenie spolku vyvolalo záujem, ktorý postupne klesal a počet účastníkov sa ustálil na úrovni približne 2/5 prvého zhromaždenia.

Počet členov sa podla dostupných údajov zásadne nemenil. Do ustanovujúceho zhromaždenia sa do spolku prihlásilo 984 členov, ako o tom informoval predseda dočasného výboru Ján Francisci. ${ }^{21}$ Približne o jeden a pol roka neskôr bol v Letopise Matice slovenskej (d’alej len v Letopise) publikovaný prvý zoznam členov, podla ktorého doň vstúpilo 1110 l'udí. ${ }^{22}$ Viliam Pauliny-Tóth po nástupe do funkcie podpredsedu, teda približne po štyroch rokoch existencie spolku, rozvinul aktivity, ktorých cielom mala byt' presnejšia evidencia členov. Výsledkom je ich súpis publikovaný tiež v Letopise. $\mathrm{V}$ porovnaní s predchádzajúcim výkazom stúpol počet o dvoch členov na $1112 .{ }^{23}$ Potenciál možných príslušníkov a podporovatelov sa vyčerpal už samotným vznikom spolku a ked' chcelo jeho vedenie priberat' d’alších, muselo podnikat' kroky, ktorými by podnietilo stotožnenie sa jednotlivcov s ideami národného hnutia. ${ }^{24}$ Zjednodušene možno povedat', že sa im to nepodarilo, pretože podla poslednej evidencie členov, publikovanej taktiež v Letopise, v druhom čísle z roku 1874 (rok pred zakázaním a rozpustením spolku), klesol počet jeho členov na $1076 .^{25}$

19 KOVÁČ, Dušan. Slovenská politika v období provizória a prípravy rakúsko-uhorského vyrovnania (1859 1867). In KOVÁČ, Dušan - KOWALSKÁ, Eva - ŠOLTÉS, Peter (eds.). Spoločnost' na Slovensku v dlhom 19. storočí. Bratislava : Veda, 2015, s. 392.

20 Spracované podla zápisníc valných zhromaždení uverejnených v Letopise Matice slovenskej.

21 Letopis Matice slovenskej, 1864, roč. 1, č. 1, s. 11.

22 Letopis Matice slovenskej, 1864, roč. 1, č. 1, s. 32-34; s. 60-86.

23 Letopis Matice slovenskej, 1867, roč. 3-4, č. 1, s. 135-159.

24 Nakol'ko bol počet členov spolku ovplyvnený aj aktivitami vládnych kruhov a župných štruktúr proti vstupovaniu do „panslavistických“ spolkov, je nateraz nezodpovedanou otázkou, ktorá si vyžaduje d’alší výskum. 25 Letopis Matice slovenskej, 1874, roč. 11, č. 2, s. 127-135. 
Členstvo v „Slovenskej Matici“ presne definovali stanovy. Podla nich sa inštitúcia skladala zo štyroch skupín členov. Prvou boli „zakladatelia“, nasledovali „riadni členovia“, „roční členovia“ a poslednú skupinu tvorili „čestní členovia“. Z toho, pre ktorú kategóriu (z prvých troch) sa eventuálny člen rozhodol, vyplývali aj jeho povinnosti a práva. Zakladatelia a riadni členovia sa po zaplatení poplatku mohli vo vol'bách uchádzat’ o zvolenie do riadiaceho orgánu spolku, ktorým bol výbor, a tak sa mohli na smerovaní a činnosti Matice aktívne podielat'. Podmienkou vstupu do spolku bolo zaplatenie členského poplatku, ktorý závisel od toho, ktorú kategóriu členstva si jednotlivec vybral. Ak chcel byt' „zakladatel’om“, musel zaplatit’ 100 zlatých. „Riadny člen“ musel uhradit’ poplatok vo výške 50 zlatých a tí, ktorí zaplatili ročne tri zlaté, patrili do kategórie „riadnych ročných členov“. ${ }^{26} \mathrm{~V}$ prípade zakladatel’ov a riadnych členov išlo o pomerne značnú sumu peňazí, ktorú musel jednotlivec v prospech spolku obetovat'. Nie každý si mohol dovolit' jednorazovo zaplatit’ členský poplatok, preto ho uhrádzal aj v splátkach. To, že išlo o vysokú sumu peňazí, potvrdzuje porovnanie s ročnými platmi, napríklad: okresný pomocný úradník v rakúskych krajinách zarábal ročne približne 700 až 800 zlatých ${ }^{27}$ a prvému podpredsedovi Viliamovi Pauliny-Tóthovi bol v roku 1866 prisúdený podobný ročný zárobok vo výške 600 zlatých. ${ }^{28} \mathrm{~V}$ porovnaní s ním boli na tom horšie dedinskí farári (aj tí lepšie situovaní nemali viac ako 500 zlatých ročne) a učitelia (ich plat sa pohyboval od 200 do 300 zlatých ročne). Ak sa chcel stat’ dedinský farár zakladajúcim členom spolku, musel sa vzdat’ viac ako dvoch mesačných platov.

Spomínané zoznamy členov nám umožňujú bližšie spoznat' sociálne a regionálne zloženie spolku a čiastočne aj jeho konfesionálnu skladbu. Hlbšia analýza členskej základne a zloženia výboru ${ }^{29}$ nám umožní lepšie interpretácie pre druhú čast' štúdie. Jednotlivé zoznamy obsahujú informácie o členovi spolku, jeho aktuálnu regionálnu (župnú) príslušnost', sociálny ekonomický status i status člena spolku. V niektorých prípadoch je možné definovat' aj jeho konfesionálnu identitu. Prvý zoznam (z roku 1864) je chronologický, jednotlivci boli zapísaní postupne, tak ako sa prihlasovali za členov. Druhý zoznam (z roku 1867) je zostavený inak, členovia boli uvedení podla svojej regionálnej/župnej príslušnosti. Tretí zoznam (z roku 1874) je podobný s druhým súpisom členov.

Ako môžeme vidiet' v tabul'ke č. 1, z Uhorska bolo viac ako 95 \% všetkých členov spolku, z iných krajín habsburskej monarchie (44 členov) a z Ruska (dvaja členovia) ich bolo čosi viac ako $4 \%{ }^{30} \mathrm{~V}$ prvom súpise členov sa nám nepodarilo regionálne identifikovat' devät’ členov,

26 Fungovanie spolku definovali jeho stanovy: Pozri viac: Letopis Matice slovenskej, 1864, roč. 1, č. 1, s. 6-9.

27 HEINDL, Waltraud. Josephinische Mandarine. Bürokratie und Beamte in Österreich. Band 2: 1848 - 1914 . Wien : Böhlau Verlag, 2013, s. 69-71.

28 Letopis Matice slovenskej, 1877, roč. 3-4, č. 1, s. 112.

29 Inšpiráciou nám bola štúdie: HROCH, Miroslav - VEVERKA, Alois. K otázce sociální skladby české obrozenecké společnosti. (Rozbor společenského složení vlastenců kolem Českého muzea a Matice české v l. 1827 až 1848.$)$ In Dějepis ve škole, 1957, roč. 4, č. 4, s. 153-159 a HUČKO, Ján. Sociálne zloženie a pôvod slovenskej obrodeneckej inteligencie. Bratislava : VEDA, 1974. Ako to už vyplýva z názvov oboch diel, autori analyzovali sociálnu skladbu určitej časti spoločnosti.

30 V rokoch 1864 a 1867 pripadlo na Prahu a české krajiny 19 členov, na Viedeň a rakúske krajiny zase 24 príslušníkov spolku. V roku 1874 sa situácia vymenila, z českých krajín mal spolok 27 členov a z rakúskych krajín 
čo predstavuje necelé percento. Podobné výsledky vyšli aj z analýzy údajov z roku 1867. Nezmenil sa počet členov spolku z iných krajín habsburskej monarchie a ani z Ruska. Devät’ osôb, ktoré sa z prvého súpisu nedali regionálne identifikovat', pripadlo na Uhorsko. V roku 1874 sa počet členov spolku znížil o 36, išlo predovšetkým o tých, ktorí umreli. Stúpol však počet členov z Ruska na sedem, išlo o nových členov, ale aj o slovenských národovcov, ktorí tam odišli za prácou.

Tab. 1 Regionálne členenie príslušníkov spolku ${ }^{31}$

\begin{tabular}{|c|c|c|c|c|c|c|}
\hline \multicolumn{7}{|c|}{ Regionálne členenie príslušníkov spolku } \\
\hline & \multicolumn{2}{|c|}{ Údaje z roku 1864 } & Údaje z roku 1867 & \multicolumn{2}{|c|}{ Údaje z roku 1874 } \\
\hline Uhorsko & 1055 & $95,05 \%$ & 1066 & $95,86 \%$ & 1026 & $95,35 \%$ \\
\hline $\begin{array}{c}\text { Ostatné krajiny } \\
\text { habsburskej monarchie }\end{array}$ & 44 & $3,96 \%$ & 44 & $3,96 \%$ & 43 & $3,99 \%$ \\
\hline Iné (Rusko) & 2 & $0,18 \%$ & 2 & $0,18 \%$ & 7 & $0,65 \%$ \\
\hline Neidentifikovaní & 9 & $0,81 \%$ & 0 & $0,00 \%$ & 0 & $0,00 \%$ \\
\hline Celkovo & 1110 & $100,00 \%$ & 1112 & $100,00 \%$ & 1076 & $100,00 \%$ \\
\hline
\end{tabular}

Pohl'ad na údaje o počte členov v jednotlivých župách môže ukázat', ako bol slovenský nacionalizmus zastúpený v jednotlivých regiónoch. Ako sa dalo očakávat', dominovali tie župy, ktoré boli z etnického hladiska prevažne slovenské. Najvyššie počty boli v Turčianskej $\left(189 / 203^{32}\right)$, Zvolenskej (182/198), Nitrianskej (156/139) a Trenčianskej župe (111/97). Pomerne vysoké počty boli ešte v Liptovskej (91/98) a Gemersko-malohontskej (78/79), Oravskej (46/46) Tekovskej (42/37) a Prešporskej župe (41/52). V piatich župách (v Hontianskej, Peštianskej, Novohradskej, Báčsko-bodrodskej a Spišskej župe) bolo viac ako 14 a menej ako 22 členov, čo predstavuje od jedného do troch percent $\mathrm{z}$ celkového počtu členov. V d'alších pätnástich župách mal spolok od jedného do siedmich svojich členov. Do činnosti spolku sa zapájali aj Slováci žijúci na Dolnej zemi, no ako vidiet', „Slovenská Matica“ mala nízku podporu na dnešnom východnom Slovenku, v Šarišskej, Abovsko-turnianskej a Zemplínskej župe, kde bolo od jedného po pät’ členov.

Zaujímavo vyznieva aj prepočet členov spolku na počet obyvatelov župy. V Turčianskej župe, ktorá patrila rozlohou aj počtom obyvatel'ov k tým menším, bolo v roku 1867 evidovaných najviac členov 205. V tomto období v nej žilo približne 45000 obyvatelov. ${ }^{33}$ Spomínaných 205

16 členov. V rokoch 1864 a 1867 boli z Ruska dvaja členovia, čo predstavuje $0,18 \%$ a v roku 1874 ich bolo sedem, čo bol nárast na hodnotu $0,65 \%$.

31 Vypracované podla zoznamov členov „Slovenskej Matice“ uverejnených v Letopisoch z rokov 1864, 1867 a 1874.

32 Prvé číslo je počet členov spolku zo súpisu z roku 1864, druhé číslo je údaj zo súpisu z roku 1867.

33 SEBŐK László (ed.). Az 1869. évi népszámlálás vallási adatai. Budapest : TLA Teleki László Intézet, KSH Népszámlálás, KSH Levéltár, 2005, s. 226. 


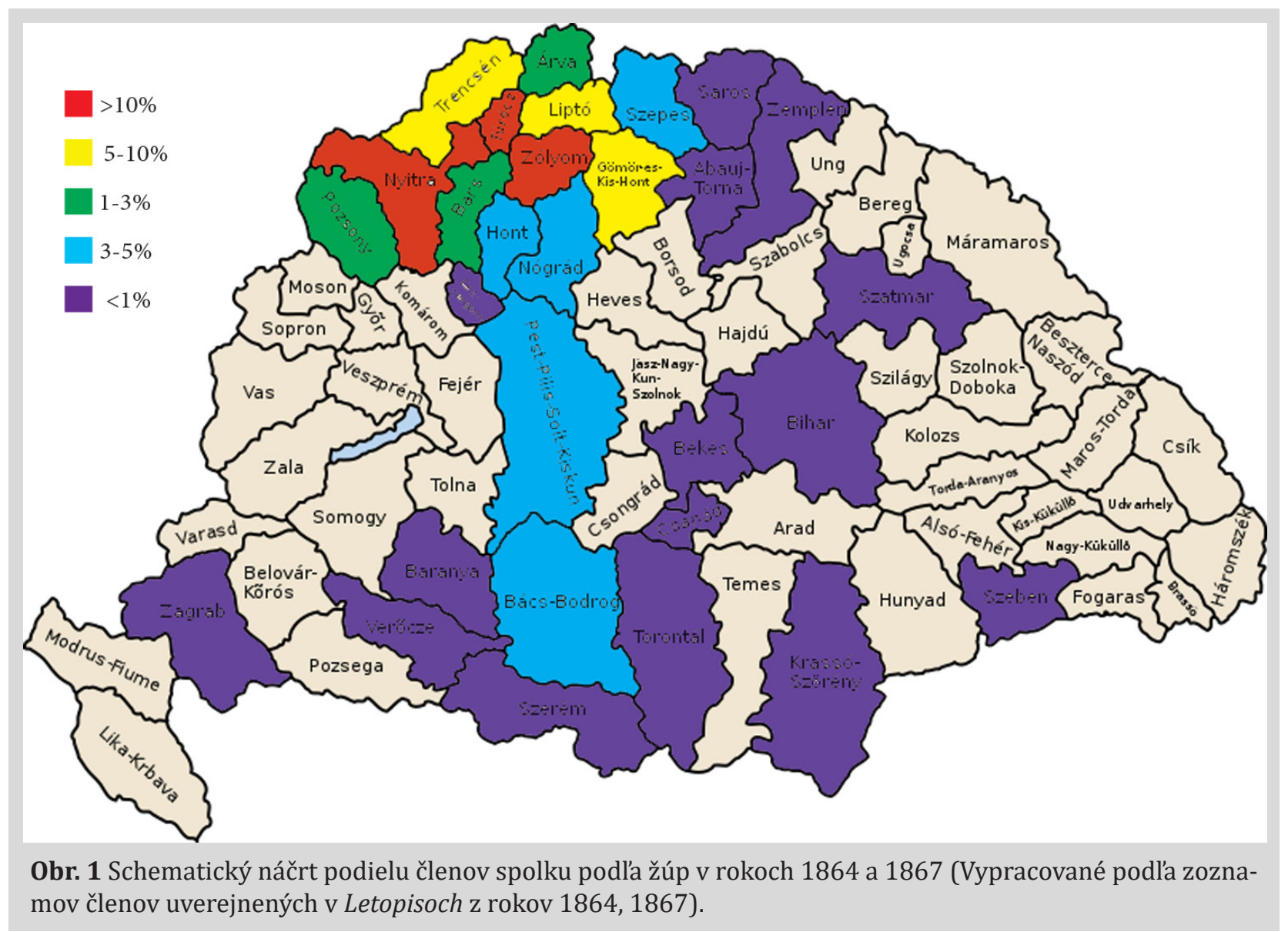

členov predstavovalo 0,4 \% z celkového počtu obyvatelov župy. Ak by sme podobne prepočítavali počet členov aj v iných župách, výsledky by ukázali ešte nižšie čísla. Tieto údaje je potrebné vidiet' v širších spoločenských a ekonomických súvislostiach. Je potrebné spomenút' vzdelanostnú úroveň celej spoločnosti. Matica vznikla ako literárny spolok, ktorý mal formovat’ morálku i vzdelanie, rozvíjat’ slovenskú literatúru a krásne umenie, ${ }^{34}$ pre nižšie vrstvy spoločnosti s triviálnym vzdelaním bol spolok neatraktívnym združením. Menej vzdelaní a nemajetní obyvatelia sa výrazne nezaujímali o takýto druh spolku, čo dokladá jeho sociálne zloženie (pozri nižšie) i snaha vedenia spolku propagovat' inštitúciu medzi nižšími spoločenskými vrstvami dobovej spoločnosti útlou, štyridsat'stranovou knihou Rozhovory o Matici slovenskej. ${ }^{35}$ Netreba zabúdat' na finančné možnosti jednotlivcov, členský poplatok si mohli dovolit' uhradit' majetnejšie vrstvy spoločnosti. No a v neposlednom rade aj nízku úroveň národnej identity.

Druhý súpis členov nám umožňuje bližší náhlad do sociálnej štruktúry spolku. Ide o pomerne rôznorodú skupinu od jednoduchých rolníkov až po panovníka Františka Jozefa. V jeho prípade išlo o formálne členstvo, no i to stačilo na zvýšenie vážnosti spolku v dobovej slovenskej národoveckej komunite. Dominantnou zložkou spolku bolo duchovenstvo, ktorého počet dosahoval takmer jednu tretinu všetkých členov. Počtom nasledovali obchodníci a meštania, ktorí tvorili presne štvrtinu členov. Učitelov a úradníkov bolo približne rovnako - 11,15 \%, respektíve 10,52 \%. Piatou najpočetnejšou kategóriou boli kolektívni členovia, ktorých bolo

34 Letopis Matice slovenskej, 1864, roč. 1, č. 1, s. 6.

35 LICHARD, Daniel Gabriel. Rozhovory o Matici slovenskej. Viedeň : Karol Goríšek, 1865. 
viac ako 7 \%. Išlo o členov, ktorí tvorili iné spolky či mestá a obce. Príslušníci slobodných povolaní (lekári, právnici, spisovatelia či vydavatelia) predstavovali viac ako 6 \% všetkých členov. Remeselníkov bolo celkovo 44, čo prestavuje takmer 4 \%. Žien bolo v spolku celkovo 25 (2,25 \%). Išlo predovšetkým o manželky národovcov, iba zriedka vystupovala žena ako členka spolku bez svojho manžela. Bohatí statkári, chudobní študenti, rol'níci, vojaci a šlachtici tvorili spolu necelé dve percentá všetkých členov. Nepodarilo sa nám identifikovat’ 12 členov spolku, čo predstavuje približne jedno percento.

Tab. č. 2 Sociálne zloženie spolku v roku $1867^{36}$

\begin{tabular}{|l|c|c|}
\hline Sociálne zloženie spolku & \multicolumn{2}{l|}{} \\
\hline Duchovenstvo & 345 & $31,03 \%$ \\
\hline Obchodníci a meštania & 278 & $25,00 \%$ \\
\hline Učitelia & 124 & $11,15 \%$ \\
\hline Úradníci & 117 & $10,52 \%$ \\
\hline Kolektívni členovia (mravné osoby) & 78 & $7,01 \%$ \\
\hline Slobodné povolania (advokát, lekár, spisovatel', vydavatel'...) & 68 & $6,12 \%$ \\
\hline Remeselníci & 44 & $3,96 \%$ \\
\hline Ženy & 25 & $2,25 \%$ \\
\hline Statkári & 8 & $0,72 \%$ \\
\hline Študenti & 6 & $0,54 \%$ \\
\hline Rol'níci & 2 & $0,18 \%$ \\
\hline Šl'achta & 2 & $0,18 \%$ \\
\hline Vojaci & 3 & $0,27 \%$ \\
\hline Nezistení & 12 & $1,08 \%$ \\
\hline Celkovo & $\mathbf{1 1 1 2}$ & $\mathbf{1 0 0 , 0 0} \%$ \\
\hline
\end{tabular}

Pre skúmanú tému je dôležité poznat’ sociálnu štruktúru riadiacich zložiek spolku, ktorú tvorili: výbor, vedenie a funkcionári. Výbor bol riadiacim orgánom, ktorý v rámci svojich kompetencií rozhodoval o určitých záležitostiach, akými boli napríklad vydavatel'ský plán, rozdelovanie štipendií i rôznych finančných podpôr, či o vyslaní spolkových zástupcov na rozličné politické a spoločenské akcie v rozmanitých kútoch habsburskej monarchie. V tejto súvislosti je dôležité zistit', či sa v ňom etablovali národovecké elity. Výbor pozostával z 30 členov, polovica bola zvolená zo zakladajúcich členov, druhá volená polovica pozostávala z riadnych členov. Podla stanov sa tretina výboru obmieňala každý rok, a to formou vol'by, ${ }^{37}$ ktorú vykonalo valné zhromaždenie. ${ }^{38}$ Počas dvanástich rokov existencie spolku sa v tomto orgáne vystriedalo 80 osobností. ${ }^{39}$

36 Vypracované podla zoznamov členov uverejnených v Letopisoch z roku 1867.

37 Každý rok sa volila tretina členov výboru. V prvých dvoch rokoch existencie spolku sa členovia, ktorí mali vystúpit' z výboru, určili žrebom.

38 Nakol'ko možno tento systém výberu označit' za prejav demokratickej vol'by a nakol'ko valné zhromaždenie volilo vopred vybraných uchádzačov, nie je možné jednoznačne povedat'.

39 Ide o týchto jednotlivcov: Michal Miloslav Hodža, Adolf Ivanovič Dobriansky, Štefan Marko Daxner, Franc 
Ked’že išlo o členov, ktorí boli volení, je možné predpokladat', že voliči vyberali spomedzi seba tých, ktorých pokladali za najlepších. Vzniklo zaujímavé spojenie rôznych národovcov vo vedení spolku. Niektorí patria aj v dnešnej slovenskej spoločnosti k všeobecne známym osobnostiam, iní sú takmer úplne nepoznaní. Priemerný vek člena zvoleného do výboru bol približne 42 rokov, $^{40}$ išlo teda o zrelých mužov, ktorí sa už v profesionálnom živote dokázali presadit’ a mali určité spoločenské postavenie.

V prípade sociálnej identifikácie členov výboru narážame na problém správneho zaradenia, ked’že niektorí členovia súčasne zastávali viaceré sociálnoekonomické pozície (mali primárne a sekundárne zamestnanie) a nie vždy sa zhodovali s ich vzdelaním. ${ }^{41}$ Súčasne sa mohli tieto pozície časom zmenit'. Pri analýze som teda vychádzal z toho pracovného zaradenia, ktoré si sami nechali zapísat' pri vstupe do výboru. Z rozboru vyplýva, že dominantnou kategóriou boli kňazi, ktorí tvorili 41,25 \%, išlo o 33 jednotlivcov. Z nich bolo 20 rímskokatolíckych kňazov, evanjelických a. v. bolo 13. Za nimi nasledovali úradníci, ktorých počet dosiahol 14. Išlo o úradníkov, ktorí v čase zvolenia do výboru zastávali posty ako mestský a župný notár, richtár, sudca, župní úradníci (hlavný slúžny, podžupan, dvorný radca pri uhorskej královskej rade, dvorný radca pri najvyššom súde vo Viedni, stoličný komisár, ale aj stoličný zememerač). Ďalšou kategóriou boli príslušníci slobodných povolaní, tu dominovali právnici, ktorých bolo osem, d’alej to boli štyria redaktori novín a jeden lekár. Medzi členmi výboru bolo jedenást' učitelov, sedem meštanov, jeden remeselník a jeden príslušník šlachtického stavu - barón. Tým bol Gregor Friesenhof, ktorého ale Viliam Pauliny-Tóth pri evidencii matičných členov zaradil medzi statkárov. ${ }^{42}$ V prípade zvolenia Gregora Friesenhofa do výboru zohral úlohu, okrem podpory slovenského nacionalizmu predovšetkým, jeho barónsky titul, ktorý mal zvýšit’ autoritu samotného výboru i spolku. Súčasne znižoval podozrenia voči spolku v očiach uhorských politických predstavitelov, župnej samosprávy i úradnej moci. ${ }^{43}$

Hánrich, Ján Gotčár, Jozef Miloslav Hurban, Martin Čulen, Ján Čipkay, Andrej Radlinský, Ján Seberiny, Jozef Karol Viktorin, Viliam Pauliny-Tóth, Gustáv Zechenter, L’udovít Thurzo Nosický, Alexander Androvič, Štefan Hýroš, Pavol Mudroň, Samuel Chalúpka, Ján Jesenský, Alexander Pongrácz, Samuel Novák, Ján Országh, Juraj Slota, Ján Kohút, Ján Gerometta, Ján Palárik, Daniel Lichard, Michal Chrástek, Jozef Škultéty, Matej Slabey, Ctiboch Zoch, Michal Algover, Franc Blaha, Jozef Bielek, Bedřich Baltík, Daniel Bôrik, Jozef Bella, Emil Černý, Pavol Dobšinský, Gregor Friesenhof, Ján Kadavý, Andrej Murčič, Ján Ondrisik, Andrej Švehla, Matej Benko, Andrej Brózik, Ludevít Hroboň, August Horislav Škultéty, Ladislav Lukáč, Ludovít Grossmann, Ján Šimko, Juraj Šoltés, Ludovít Sartoris, Maximilián Hudec, Samuel Ormis, Martin Kramár, Pavol Mác, Jozef Nedobrý, Ján Kalinčiak, Daniel Bachát, Ján Mallý, Mikuláš Ferienčík, Andrej Lemeš, Jozef Kohuth, Samuel Lányi, Ján Capko, Franko Hreusík, Jozef Kohút, Žigmund Melfelber, Franko Taganyi, Jozef Horváth, Ján Belička, Ján Drahotín Makovický, Ján Rehák, Jozef Kajuch, Pavol Tergina, Anton Nádašy, Ambro Pietor, Jozef Samuely, Jozef Országh.

40 V šiestich prípadoch sa nám nepodarilo identifikovat’ vek výborníkov, v akom boli zvolení do funkcie.

41 Napríklad Ján Gotčar bol predstaveným kláštora a súčasne aj školským radcom, teda prelína sa úradnícka kategória s kňazskou, v prípade Viliama Paulinyho-Tótha sa prepletá funkcia redaktora novín, teda status slobodného povolania s kategóriou úradníka, v prípade Augusta Horislava Škultétyho sa zase prelína socioekonomická pozícia farára s funkciou riaditela revúckeho gymnázia.

42 Viac pozri: Letopis Matice slovenskej, 1867, roč. 3-4, č. 1, s. 135-159.

43 HOLEC. Roman. Barón v službách rolníka (Gregor Friesenhof). In HOLEC, Roman. Zabudnuté osudy. Martin : Matica slovenská, 2001, s. 74.0 vztahu Gregora Friesenhofa k slovenskému národnému hnutiu pozri viac: HOLEC, Roman. Barón Friesenhof v kontexte vel'kej doby a malých dejín. In ĎURIŠKA, Zdenko (ed.). Biografické štúdie 38, Martin : Slovenská národná knižnica, s. 46-48. 
Celkovo zloženie výboru vyzerá v prospech kňazov. Pri porovnaní prvého (v roku 1863) a posledného ( $v$ roku 1874) spolkového výboru uvidíme značný posun v jeho sociálnej a zamestnaneckej skladbe. V roku 1863 boli vo výbore deviati duchovní a jeden právnik, v roku 1874 sa situácia zmenila. Počet právnikov sa zvýšil na devät' a začínali dominovat', ked’že počet kňazov ${ }^{44}$ klesol na sedem. Ako vidiet', v národnom hnutí začali popri kňazoch aktívne vystupovat' najmä osoby s právnickým vzdelaním, čo je, ako si ukážeme nižšie, aj dôsledok spolkovej stratégie pri výchove nových generácií národných elít.

Tab. 3 Sociálne zloženie členov výboru spolku v rokoch 1863 - $1875^{45}$

\begin{tabular}{|l|c|c|}
\hline \multicolumn{3}{|c|}{ Sociálne zloženie výboru spolku } \\
\hline Duchovenstvo & 33 & $41,25 \%$ \\
\hline Úradníci & 14 & $17,50 \%$ \\
\hline Slobodné povolania (advokát, lekár, spisovatel', vydavatel'...) & 13 & $16,25 \%$ \\
\hline Učitelia & 11 & $13,75 \%$ \\
\hline Obchodníci a mešt’ania & 7 & $8,75 \%$ \\
\hline Remeselníci & 1 & $1,25 \%$ \\
\hline Šl'achtici & 1 & $1,25 \%$ \\
\hline Celkovo & 80 & $100 \%$ \\
\hline
\end{tabular}

V prípade kňazov v spolkovom výbore ide o mix nižšieho a čiastočne aj vyššieho duchovenstva. Členmi boli v prípade katolíckej konfesie na jednej strane bežní dedinskí farári, na strane druhej dekani, arcidiakoni a opáti. V prípade evanjelickej konfesie ide o podobné spojenie dedinských farárov so seniormi evanjelickej cirkvi. Obdobne pestrú skladbu nájdeme aj v prípade úradníckych profesií. Členmi výboru boli vyššie postavení úradníci (cisársko-královský dvorný radca, podžupan) i zástupcovia nižších úradníckych postov (mestský notár). V prípade učitel'ov išlo prevažne (devät' z jedenástich) o pedagógov pôsobiacich na vyšších typoch škôl, predovšetkým na gymnáziách, no nie o dedinských učitel’ov. Nezriedka išlo o samotných riaditel'ov týchto gymnázií. Obchodníci, remeselníci a meštania tvorili desat' percent z celkového počtu výborníkov. $\mathrm{V}$ tomto prípade išlo o finančne zabezpečených príslušníkov spoločnosti (napr. Ján Čipkay dlhodobo finančne podporoval národné hnutie ${ }^{46}$ ) alebo o tých, ktorí sa dokázali presadit’ v mestskej správe (Andrej Švehla, ktorý bol richtárom Turčianskeho Sv. Martina viac ako štvrt'storočie).

Do spolkového výboru boli zvolení predovšetkým l'udia s vyšším vzdelaním. Išlo prevažne o tých, ktorí absolvovali stredný a vyšší stupeň škôl. Len protagonisti s vyšším vzdelaním sa podla Miroslava Hrocha dokázali aktívne podiel'at' na politických a sociálnych činnostiach

44 Medzi kňazov počítame aj Martina Čulena, ktorý bol v súpise vedený ako riaditel' gymnázia, nie ako klerik, čo bol z hladiska národného hnutia dôležitejší status.

45 Vypracované podla zápisníc výborových zasadnutí v rokoch 1863 - 1875 uverejnených v Letopisoch Matice slovenskej v spomenutých rokoch. Ide o súčet všetkých členov počas celého obdobia.

46 BOTTO, Dejiny Matice slovenskej 1863 - 1875, citované z: http://zlatyfond.sme.sk/dielo/902/Botto_DejinyMatice-Slovenskej-1863-1875/1 
v záujme vyššej, teda národnej pospolitosti. ${ }^{47}$ Ked’že dokázali zaplatit' celú výšku členského poplatku, ${ }^{48}$ možno konštatovat', že aj z finančného hl'adiska išlo o pomerne dobre zabezpečených jednotlivcov.

Dôležité je ale odpovedat' na otázku, nakol'ko sa jednotliví výborníci aktívne podiel'ali na vedení spolku a mali ambíciu podiel'at' sa na rozhodovaní. Výbor sa schádzal približne štyrikrát v priebehu kalendárneho roka. $V$ januári, v máji (výnimočne v júni) a dvakrát v auguste, deň pred valným zhromaždením a po valnom zhromaždení. Výnimkou boli tri jesenné zasadnutia: dvakrát v októbri a raz v septembri. Celkovo sa uskutočnilo 48 zasadnutí, z toho dve boli mimoriadne. V priemere bola na zasadnutiach výboru 34,48 \% účast'. Tá je pravdepodobne dôsledkom viacerých faktorov, akými boli: nerozvinutá dopravná infraštruktúra v Uhorsku a s tým spojené komplikované cestovanie (železničná trat', ktorá napojila sídlo Turčianskej župy na uhorskú siet' železníc sa dobudovala v roku 1872), d’alším zdôvodnením mohlo byt' aj to, že každý výborník musel sám znášat’ finančné výdavky spojené s cestovaním a účast' nebola honorovaná, išlo o dobrovol'nú aktivitu. V neposlednom rade výborníci mali vlastné pracovné povinnosti.

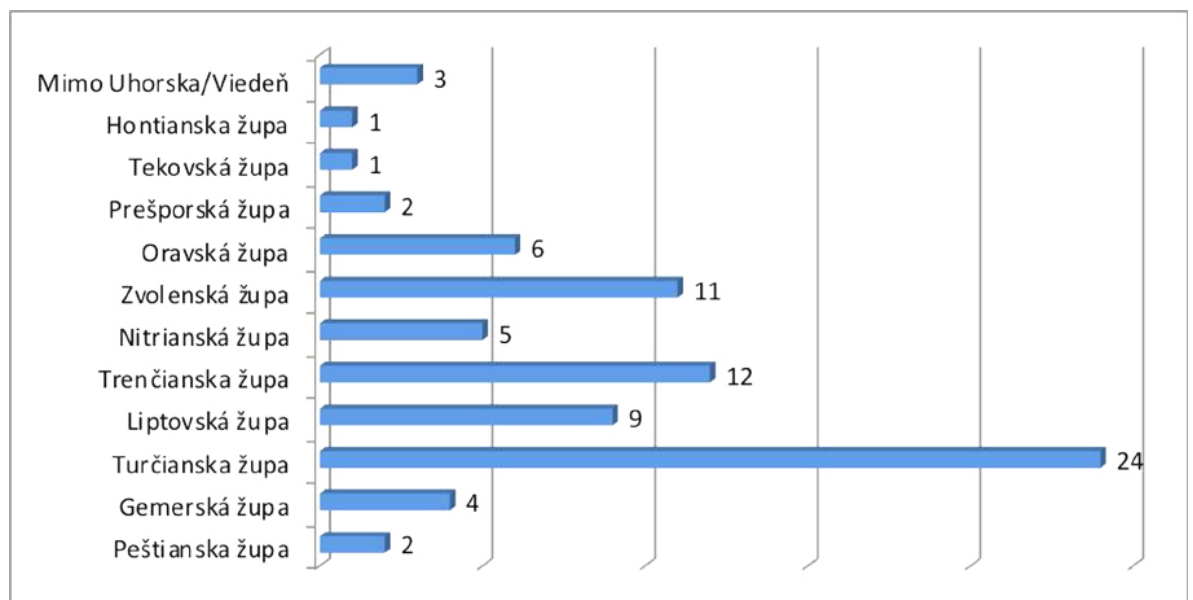

Graf č. 1 Regionálne zastúpenie členov výboru podla žúp v rokoch $1863-1875 .^{49}$

Ked' porovnáme členov prvého a posledného matičného výboru, zistíme, že v roku 1863 boli z Turčianskej župy vo výbore len dvaja národovci, $\mathrm{v}$ roku 1874 až osemnásti. Aj napriek personálnej centralizácii vedenia spolku do Turca sa účast’ na zasadnutí výboru markantne nezvýšila. Z celkového počtu 80 výborníkov sa 17 ani raz nezúčastnilo zasadnutia, pričom 48 z nich malo menej ako štvrtinovú účast'. Viac ako 50 \% zasadnutí výboru sa zúčastnilo 20 členov, z nich ôsmi boli prítomní na troch štvrtinách možných zasadnutí. Tieto čísla však môžu vytvárat' skreslujúci obraz, pretože z 80 výborníkov boli 16 členmi výboru iba jeden rok a z nich ôsmi mali možnost' navštívit' iba dve zasadnutia (na jednej strane sa napr. ružomberský evanjelický farár Ján Drahotín Makovický nezúčastnil ani jedného z dvoch možných, na druhej strane sa mladý právnik Ambro Pietor, bývajúci v sídle spolku, zúčastnil oboch možných zasadnutí). Ak odrátame tých, ktorí boli členmi iba jeden rok, stále zostáva dvanást’ výborníkov, ktorí sa ani raz nezúčastnili zasadnutia. Z nich najnižšiu účast' mal Adolf Ivanovič Dobriansky, ktorý mal možnost’ zúčastnit'

47 HROCH, Miroslav. Národy nejsou dílem náhody. Praha : Slon, 2009, s. 121-122.

48 Uhradit' celú sumu 100, resp. 50 zlatých sa nepodarilo všetkým jednotlivcom, ktorí sa prihlásili za členov.

49 Vypracované podla zápisníc výborových zasadnutí v rokoch 1863 - 1875 uverejnených v Letopisoch Matice slovenskej v spomenutých rokoch. Ide o súčet všetkých členov počas celého obdobia. 
sa tridsiatich troch zasadnutí, no nebol ani na jednom. Dobrianskeho členstvo v spolku a vo výbore teda možno považovat' za skôr formálne, ale pre samotný spolok to bola prestíž, ked'že išlo aktívneho politika s vplyvnými kontaktmi na viedenské a uhorské vládne kruhy. Ked' som spomenul najväčších absentérov, spomeniem aj najpoctivejších účastníkov. Najaktívnejšiu účast’ na zasadnutiach výboru mali Mikuláš Ferienčík, Jozef Horváth a Martin Čulen. Prví dvaja pôsobili priamo v Turčianskom Sv. Martine, Ferienčík ako redaktor novín a Horváth ako miestny evanjelický farár. Tretí, Martin Čulen, bol v čase existencie spolku profesorom na gymnáziu v Banskej Bystrici, neskôr riaditel’om gymnázia v Kláštore pod Znievom a ako celibátnik bez rodiny mal viac času na spolkové záležitosti. Vyššie uvedené čísla nemožno preceňovat', predpokladám, že účast' na výborových zasadnutiach i samotné zloženie výboru by boli iné, ak by bolo sídlom spolku iné mesto. ${ }^{50}$

\section{Spolkové štipendium ako stratégia vytvárania nových a lojálnych národo- veckých elít}

Spolok z členských príspevkov, ako aj z rôznych darov disponoval finančným kapitálom, ktorý využíval rozlične. Už na prvom valnom zhromaždení predseda prípravného výboru Ján Francisci verejne konštatoval, že v prospech spolku bol finančný kapitál vo forme úpisu vo výške 83901 zlatých a 95 grajciarov. Táto suma ešte celá nebola odovzdaná účtovníkom, tí disponovali s financiami vo výške 29862 zlatých a 19 grajciarov. ${ }^{51}$ Aj v prípade disponibilnej sumy išlo o pomerne hodnotný obnos financií. Tie sa podarilo vyzbierat' aj vd’aka eufórii, ktorá v národoveckých kruhoch zavládla po verejnom oznámení úradného potvrdenia stanov. O došlých finančných daroch a členských poplatkoch podrobne informovali Pešt'budínske vedomosti. Tým, že sa v novinách uverejňovali tieto informácie, predišlo sa prípadným obvineniam zo sprenevery financií, no súčasne to zrejme bol aj dobrý marketingový t’ah, ktorý motivoval aj iných, aby sa stali členmi spolku.

Pred vedením novovzniknutého spolku bola dôležitá otázka: Ako využit' nazbierané financie v prospech národného hnutia? Vedenie spolku - výbor - podla stanov nemohol nakladat' s celou vyzbieranou sumou, iba s tou čast'ou, ktorá bola ziskom z úročenia peňazí. ${ }^{52} \mathrm{Z}$ týchto financií sa následne napríklad financovali vydavatel'ské projekty, podporovali mladí študenti formou štipendií či udel'ovali podpory pre alumneum gymnázií v Banskej Bystrici a vo Vel'kej Revúcej. Tým, že vedenie spolku investovalo finančný kapitál do mladých študentov, očakávalo z ich strany lojalitu voči národnému hnutiu. Súčasne dúfalo, že vytvoria nové generácie prívržencov a lídrov národného hnutia, ktorí sa aktívne zapoja aj do činnosti spolku. Mladí poslucháči fakúlt, takmer všetci právnici, sa už prostredníctvom žiadosti o štipendium prezentovali medzi staršími, ostrielanými národovcami a budovali si siet’ vlastných sociálnych kontaktov. Po skončení štúdia mnohí praxovali ako koncipienti v právnických kanceláriách tých národovcov, ktorí im odhlasovali štipendium.

50 Ešte pred vznikom spolku sa hladalo jeho sídlo, uvažovalo sa o Brezne, ktoré najskôr súhlasilo s prijatím Matice, no neskôr svoje rozhodnutie zmenilo.

51 Letopis Matice slovenskej, 1864, roč. 1, č. 1, s. 12-13.

52 S akým finančným kapitálom, ktorý vzišiel z úročenia peňazí spolok hospodáril, dnes nevieme jednoznačne povedat'. Táto otázka si vyžaduje hlbší výskum. 
Spolok udeloval štipendiá v rokoch 1864 až $1868 .^{53} 0$ pridelení, resp. nepridelení finančnej podpory rozhodoval výbor na januárových zasadnutiach. Zaujímavostou je, že štatisticky bolo na týchto schôdzach najmenej členov, v spomínaných rokoch to bolo v priemere desat' členov výboru, teda jedna tretina. Nebránilo to možnosti rozhodnút’ v otázkach štipendií, pretože výbor bol podla stanov uznášaniaschopný, ak sa ho zúčastnilo aspoň šest' členov. ${ }^{54}$

Záujem o štipendiá zo strany mladých poslucháčov bol značný, počas celého obdobia, ked' boli udelované, dopyt prevyšoval finančné možnosti spolku. Preto možno pri uvažovaní o podporených študentoch vychádzat' z predpokladu, že členovia výboru vyberali spomedzi kandidátov tých najlepších, a to na základe poslaných životopisov a vysvedčení, neskôr aj na základe odporúčaní, ktoré mali ašpirantom vystavit' starší, etablovaní národovci. 0 tom, že spolok bude udel'ovat' štipendiá, sa rozhodlo už na jeho prvom valnom zhromaždení 4. augusta 1863. Podla publikovanej zápisnice návrh predostrel predseda spolku, banskobystrický biskup Štefan Moyzes: „[...] po zapravení všetkých bežných útrat z ustanovenej $k$ tomu od výboru na bežiaci rok sumy 1/3 na vydávanie spisov a 2/3 na podporovanie a štipendia chudobných nádejoplných žiakov slov., obojeho vyznania [...]." Návrh vzbudil diskusiu, ozval sa Martin Hattala a predostrel ideu, aby sa spolok viac sústredil „plodom literárnym, nežli na podporovanie žiakov a štipendiá. ${ }^{\text {55 }}$ Hattalova myšlienka sa ale podl'a zápisnice nestretla so súhlasom a v platnosti ostal pôvodný Moyzesov koncept. Na druhý deň sa však situácia zopakovala, ked’ podobný návrh ako Hattala predostrel aj jeden z autorov spolkových stanov a doživotný čestný predseda Ján Francisci. Argumentoval práve znením stanov, v ktorých neboli špecifikované podrobnosti udelovania štipendií. Celá vec sa nakoniec uzavrela kompromisom, na štipendiá pripadla každý rok istá disponibilná suma. Na rok 1864 sa definovala podpora vo výške 125 zlatých pre štyroch študentov. Už na ustanovujúcom výbore sa zadefinovalo, že uprednostňovaní budú študenti práva. ${ }^{56} 0$ možnostiach, ako získat' finančnú podporu od spolku, informovali Pešt'budínske vedomosti. Študenti mali poslat' odôvodnené žiadosti spoločne s vysvedčeniami. Štvrté výborové zasadnutie ${ }^{57} \mathrm{v}$ januári 1864 vybralo nakoniec šest’ uchádzačov: Jána Cebecauera, ${ }^{58}$

53 Podla dostupných prameňov nevieme jednoznačne povedat', prečo spolok po roku 1868 už neposkytoval štipendiá.

54 Fungovanie Výboru podrobne upravuje $\S 21$ stanov spolku. Letopis Matice slovenskej, 1864, roč. 1, č. 1, s.

55 Letopis Matice slovenskej, 1864, roč. 1, č. 1, s. 31.

56 Letopis Matice slovenskej, 1864, roč. 1, č. 1, s. 39.

57 Letopis Matice slovenskej, 1864, roč. 1, č. 1, s. 56.

58 Krátke biografické medailóny zamerané na aspekt sociálneho pôvodu, štúdia a socioekonomické zaradenie sú vypracované z viacerých zdrojov (Slovenský biografický slovník, Biografický lexikón Slovenska). Ich advokátsku kariéru som sa snažil identifikovat' podla publikácie KEREČMAN, Peter - MANÍK, Rudolf. História advokácie na Slovensku. Bratislava : Eurokódex, 2011 a podla dobovej štatistiky Magyarország Tiszti Czím- és Névtára. Cebecauer, Ján $(* 1843$ - †?) pochádzal z Liptova z Královej Lehoty, bol študentom na katolíckom gymnáziu v Banskej Bystrici, kde od roku 1867 pôsobil aj ako učitel. Od roku 1870 pôsobil ako pedagóg na katolíckom gymnáziu v sedmohradskom meste Sibiu (Nagyszeben). Ako mladý študent a pedagóg sa prezentoval ako zapálený národovec. Po odchode do Sedmohradska sa angažoval v národnom hnutí len náznakovo, a to i napriek tomu, že bol členom Matice a prispel aj na alumneum katolíckeho gymnázia v Kláštore pod Znievom. Za pomoc pri bližšom identifikovaní d’akujem Mgr. Tomášovi Adamčíkovi, PhD. 
Jozefa Holécyho, ${ }^{59}$ Jozefa Kohúta, ${ }^{60}$ Vendelína Kutlíka, ${ }^{61}$ Aloisa Mráza ${ }^{62}$ a Jozefa Strakoviča. ${ }^{63}$ Podla vyplatených peňazíi ${ }^{64}$ boli dodatočne podporení ešte dvaja študenti: Milan Trokan, ${ }^{65}$ Samuel Zachej. ${ }^{66}$

V prvom roku existencie spolku bol špeciálnym štipendistom Ján Nepomuk Bobula. Ten bol prítomný na augustovom valnom zhromaždení a vedel, že spolok bude študentov finančne podporovat'. Bobula nečakal na zverejnenie výzvy, ale sám už v septembri 1863 napísal biskupovi Moyzesovi a žiadal o udelenie štipendia. Moyzes ho podporil z vlastných peňazí sumou 15 zlatých mesačne. Zapojil sa aj do súbehu o štipendiá, ale neuspel, čo vyvolalo jeho rozhorčenie, ktoré sa skončilo prerušením kontaktov so spolkom. ${ }^{67}$ Bobulu neradíme medzi spolkových štipendistov, ked’že financie dostal priamo od biskupa. Celkovo sa o matičné štipendium už v prvom roku uchádzalo jedenást' mladých „súbežníkov“..68 Dvoch z troch, ktorí neuspeli, sa nám nepodarilo identifikovat', ked’že vedenie spolku im vrátilo všetky podklady, žiadosti a vysvedčenia.

V d’alšom roku (1865) už prišlo devätnást' žiadostí o štipendium. Podl'a výborovej zápisnice bolo štipendium pridelené opät’ ôsmim študentom. Polovica žiadatelov (Ján Cebecauer, Žigmund Melferber, ${ }^{69}$ Peter Jamnický, ${ }^{70}$ Alojz Mráz) dostala štipendium vo výške 125 zlatých, druhá polovica (Jozef Strakovič, Jozef Holécy, Milan Trokan, Samuel Zachej) bola podporená

59 Holécy, Jozef $(*-\uparrow ?)$ bol študentom práva v Pešt'budíne, neskôr pôsobil ako právnik v Liptovskom Sv. Mikuláši.

60 Kohút, Jozef (*13. apríl 1838 - † 16. máj 1915) právo vyštudoval v Pešti a od roku 1868 pôsobil ako právnik v Turčianskom Sv. Martine. V meste bol spoločensky aktívny, hrával v spevokole, bol spoluzakladatelom dobrovol'ného hasičského spolku, bol tiež členom matičného výboru.

61 Kutlík, Vendelín (* 5. apríl 1834 - † 4 jún 1906) bol synom evanjelického farára. Vyštudoval právo v Bratislave a Pešti. Pracoval v advokátskej kancelárii Michala Mudroňa, od roku 1867 mal vlastnú prax v Trnave, od roku 1874 v Bratislave. Prispieval do slovenských periodík. Za manželku mal dcéru Michala Miloslava Hodžu.

62 Mráz, Alojz (*?- †?) právo študoval v Bratislave, zomrel ešte počas štúdia v roku 1867.

63 Strakovič, Jozef (*10 december 1840 - † 14 marec 1909) pochádzal z rol'níckej rodiny. Právnické vzdelanie nadobudol v Pešti a vo Viedni. Usadil sa v Pešti, kde pôsobil ako praktikant na uhorskej královskej tabuli, neskôr mal v hlavnom meste Uhorska vlastnú advokátsku firmu. Spolupracoval s Novou školou, neskôr sa však s Bobulom nepohodol. Vydával beletristický mesačník Dunaj.

64 Archív Matice slovenskej (d’alej A MS), fond (d’alej f.) Matica slovenská (1857) 1863 - 1875 (1912) I., sign. 201. K téme pozri aj KAČ́́REK, L'uboš. Vztáah Novej školy slovenskej k Matici slovenskej. In SEDLÁK, Imrich (ed.). Matica slovenská v národných dejinách. Martin : Matica slovenská, 2013, s. 59 - 69.

65 Trokan, Milan (*1844 - †1888) pochádzal z rodiny evanjelického kňaza Jána Trokana pôsobiaceho na Myjave. Právo vyštudoval v Bratislave a ako právnik pôsobil na Myjave.

66 Zachej, Samuel (* 31. marec 1841 - † 4. február 1918) pochádzal z rodiny banského úradníka. Študoval na gymnáziu v Banskej Bystrici, kde sa stal Moyzesovým chránencom, na jeho odporúčanie študoval teológiu v Pešti, v rokoch 1869 - 1874 bol profesorom patronátneho gymnázia v Kláštore pod Znievom. Pôsobil aj ako zástupca riaditel’a Martinskej sporitel'ne, roku 1878 sa odst'ahoval do Bukurešti, kde mal vlastnú obchodnú spoločnost'.

67 A MS, f. Matica slovenská (1857) 1863 - 1875 (1912) I., sign. 194.

68 Letopis Matice slovenskej, 1864, roč. 1, č. 1, s. 56.

69 Melferber, Žigmund (* 24. december 1843 - † 19. november 1923) pochádzal z rodiny evanjelického farára. Právo vyštudoval vo Viedni. Od roku 1868 mal v Turčianskom Sv. Martine samostatnú právnickú prax, bol advokátom Kníhtlačiarsko-účastinárskeho spolku, v rokoch 1881 - 1888 bol richtárom Martina. Pôsobil aj vo výbore spolku „Slovenská Matica“.

70 Jamnický, Peter (* 1840 - † 1908) študent práva v Pešti, neskôr pôsobil v Pezinku, kde mal vlastnú advokátsku kanceláriu. Častokrát spolupracoval s bratmi Mudroňovcami. Jeho syn Otakar bol tiež právnikom. 
50 zlatými. Z nich takisto ako v predchádzajúcom roku dvaja (Cebecaurer a Zachej) neboli študentmi práva. Oproti predchádzajúcemu roku spolok podporil dvoch nových študentov. Pri rozdel'ovaní finančných podpôr sa viedla pomerne vášnivá diskusia, ktorá mala za následok spresnenie pravidiel pri udelovaní štipendií. ${ }^{71}$ Vypracovaním zásad udelovania boli poverení právnici L'udovít Thurzo Nosický a František Martinkovič. Výsledok sa dotýkal predovšetkým nasledujúcich záležitostí: „[...] sa majú raz udelené štipendiá a podpory mat. patričným mladíkom tak dlho ponechat', pokým bud'že sa oni takých či nemravnost'ou, či nedbanlivostou, alebo odrodilstvom [zvýraznil R.M.] nehodným nestali, bud’že ináče sami sa nezaopatria; [...] majú sa o ne povždy znovu uchádzat' [...] a majú k svojim prosbopisom [...] požadované prílohy pripojit;' menovite: a) školské vysvedčenia, jako sa kde dla zákona vydávat' zvykly; b) svedectvo mravnosti a chudoby od farského úradu svojej domoviny; c) krátky svoj životopis a d) odporúčanie aspoň dvoch všeobecne známych národovcov a účastníkov na Matici. ${ }^{\text {"72 }}$ Okrem dobrého študijného prospechu a slabej sociálnej situácii uchádzača sa dôraz kládol aj na odporúčania národovcov i na to, aby spolok nepodporoval „odrodilcov“. Ašpiranti na štipendiá začali oslovovat’ etablovaných národovcov zo svojho okolia a do súbehov o štipendiá posielali aj ich odporúčania. Tie boli kladné, podpísané samotnými členmi spolku, či už zo samotného vedenia (Karol Kuzmány), výboru (napr. Jozef Miloslav Hurban, Pavol Mudroň, Ján Kohút, Ján Drahotín Makovický), ale aj radovými členmi spolku z regiónov. ${ }^{73}$

Zmena pravidiel profesionalizovala udelovanie finančnej dotácie a v niektorých bodoch sa podobá dnešným podmienkam, ktoré musia žiadatelia uchádzajúci sa o štipendiá od rôznych organizácii splnit'. Od roku 1866 sa zvýšil aj počet udelených štipendií, stúpol na dvanást'. No i napriek tomu dopyt stále prevyšoval ponuku. V roku 1866 sa o štipendium uchádzalo dvadsat’jeden poslucháčov škôl. V tomto roku boli financie pridelené siedmim novým študentom

71 Letopis Matice slovenskej, 1870, roč. 2, č. 1, s. 32.

72 Letopis Matice slovenskej, 1867, roč. 3-4, č. 1, s. 53.

73 Pozri viac odporúčania v archíve spolku: A MS, f. Matica slovenská (1857) 1863 - 1875 (1912) I., sign. 729 až 746. 
(Anton Pavel Bulla, ${ }^{74}$ Matúš Dula, ${ }^{75}$ Cyril Hodža, ${ }^{76}$ Peter Krno, ${ }^{77}$ Miloslav Kulíšek, ${ }^{78}$ Samuel Medvecký ${ }^{79}$ František Veselovský ${ }^{80}$ ), dvom zostalo v nezmenenej výške (Ján Cebecaurer a Alojz Mráz), a trom sumu zvýšili na 125 zlatých (Jozef Strakovič, Milan Trokan, Samuel Zachej). ${ }^{81}$ V roku 1866 vedenie spolku udelilo štipendiá v najvyššej výške, celkovo v sume 1275 zlatých. V nasledujúcom roku (1867) bolo udelených tiež dvanást' štipendií, ${ }^{82}$ no znížila sa celková suma, ktorá klesla na 1050 zlatých. ${ }^{83}$ Podporení boli dvaja (traja - ak počítame aj Ambra Pietra ${ }^{84}$ ) noví študenti: Emil Zachar ${ }^{85}$ a Baltazár Tomko ${ }^{86}$. Rok 1868 bol posledným, ked' spolok udelil finančné podpory, ktorých celková výška činila menej ako polovicu v porovnaní s rokom

74 Bulla, Anton Pavel (*29. január 1843 - † 5. september 1873) pochádzal z remeselníckej rodiny, otec bol kováčom. Vyštudoval právo v Bratislave a neskôr pôsobil ako advokátsky koncipient a ako župný a pomocný úradník v Dolnom Kubíne. Zomrel mladý počas epidémie cholery, bezdetný. Jeho bratom bol architekt Blažej Bulla.

75 Dula, Matúš (*28. jún 1846 - †13. jún 1926) pochádzal z Blatnice v Turci z rol'níckej, možno povedat',že národne uvedomelej rodiny, ked'že otec bol členom spolku „Slovenská Matica“, no súčasne aj finančne zabezpečenej ked'že dokázal uhradit' členský poplatok. Matúš Dula právo vyštudoval vo Viedni a pôsobil ako advokát v Martine, za manželku mal dcéru Viliama Paulinyho-Tótha. Dula bol politicky aktívny, stal sa vedúcou osobnostou Slovenskej národnej strany a bol jedným zo signatárom Deklarácie slovenského národa.

76 Hodža, Cyril (*15. september 1844 - † 27 jún 1914) bol synom evanjelického farára Michala Miloslava Hodžu. Cyril Hodža vyštudoval právo v Bratislave a vo Viedni. Od roku 1875 pôsobil ako advokát Trnave. Prispieval do viacerých slovenských novín a časopisov.

77 Krno, Peter (*?- †?) právo vyštudoval vo Viedni, pôsobil ako notár v hontianskej dedine Beluj a neskôr ako advokát vo Váci.

78 Kulíšek, Miloslav (* 4. august 1843 - † 15 apríl 1910) pochádzal z učitel'skej rodiny, právo vyštudoval v Bratislave. Bol koncipientom v právnickej kancelárii Pavla Mudroňa, neskôr mal vlastnú právnickú prax v Novom Meste nad Váhom. Kulíšek sa neskôr sám stal mecénom slovenských študentov, ktorí študovali na prelome 19. a 20. storočia na Morave a v Čechách.

79 Medvecký, Samuel (*30. júl 1845 - † 1. júl 1896) syn evanjelického kňaza Samuela Medveckého zo Zvolenskej Slatiny. Právo vyštudoval v Pešti. Po štúdiu pôsobil ako advokát vo Zvolene. Bol prívržencom Slovenskej národnej strany, no kritizoval jej pasivitu. Bol tiež spoluzakladatelom a správcom sporitel'ne vo Zvolene. Ako literát prispieval do slovenských novín a časopisov poéziou i publicistikou. Aj jeho sestry sa vydali za „národovcov“. Prvá, Adela, za Jána Čajaka, neskôr za Pavla Dobšinského. Druhá, Terézia, sa vydala za Jána Vansu. Syn Samuela Medveckého L’udovít bol tiež právnikom.

80 Veselovský, František (* 30. september 1845 - † 13. marec 1917) právo vyštudoval v Bratislave, ako advokát pôsobil v Trnave. Bol zakladatel' a správcom Trnavskej a vidieckej l'udovej banky, právnym poradcom a funkcionárom Spolku Sv. Vojtecha. Bol tiež sympatizantom Katolíckej ludovej strany, i členom Slovenskej národnej strany. V rokoch 1901 - 1905 bol ako člen Slovenskej národnej strany poslancom Uhorského snemu za Senický volebný obvod.

81 Letopis Matice slovenskej, 1867, roč. 3-4, č. 1, s. 80.

82 Dvanást' štipendií bolo rozdelených trinástim štipendistom, Alojz Mráz zomrel, pričom mu bola vyplatená len polovica sumy, druhú polovicu dostal Ambro Pietor.

83 Letopis Matice slovenskej, 1867, roč. 3-4, č. 1, s. 120.

84 Pietor, Ambro $(* 15$. november 1843 - † 3. december 1906) pochádzal z remeselníckej rodiny, otec bol murárom. Právo vyštudoval vo Viedni a následne sa usadil v Turčianskom Sv. Martine. Tu pôsobil ako právnik, no aj ako redaktor Národných novín.

85 Zachar, Emil $(* 18$. január 1846 - † 15. marec 1917) pochádzal z rodiny mestského notára, právo študoval v Prešove. Viedol vlastnú právnu kanceláriu, v roku 1872 sa stal členom banskobystrického súdu, v roku 1904 predsedom senátu súdnej tabule, v roku 1908 predsedom senátu Uhorskej královskej kúrie v Budapešti. Právnikom sa stal aj jeho syn Július.

86 Tomka, Baltazár (* 6. január 1845 - † 20. január 1889) právo študoval v Pešti, kde pôsobil aj ako revízor a zapisovatel' zápisnice Pomocnej pokladnici v Pešti. Po štúdiách sa usadil v Turčianskom Sv. Martine, kde pôsobil ako úradník a bol aktívnym členom národného hnutia. 
1866, išlo o sumu 600 zlatých. Opät’ boli podporení dvanásti študenti, ${ }^{87} \mathrm{z}$ toho piati noví: Svetozár Hurban, ${ }^{88}$ Žigmund Hudec, ${ }^{89}$ František Mráz, ${ }^{90}$ Ján Karol Porubský $^{91}$ a Jozef Schuster. ${ }^{92}$

Celkovo vedenie spolku podporilo dvadsat'pät' študentov a udelilo im subvenciu vo výške 4325 zlatých a 50 grajciarov. Najviac peňazí dostali Alois Mráz (437 zlatých a 50 grajciarov) a Ján Cebecauer (425 zlatých). Najmenej peňazí udelili Svetozárovi Hurbanovi a Jánovi Karolovi Porubskému, každému po 30 zlatých. Cielavedome, rozhodnutím prvého valného zhromaždenia spolku, boli podporovaní študenti práva. Zo spomínaných dvadsiatich piatich len dvaja (Ján Cebecauer a Samuel Zachej) neštudovali právo.

Snaha slovenského národného hnutia o formovanie novej generácie právnikov siahala minimálne do začiatku 60. rokov 19. storočia. Už v Memorande sa požadovalo založenie právnickej akadémie so slovenským vyučovacím jazykom. ${ }^{93}$ Podobne je právnická akadémia predmetom slovenskej prosby vyslovenej prostredníctvom biskupa Bosny a Sriemu Josipa Juraja Strossmayera na zasadnutí ríšskej rady. Táto akadémia mala podla slovenského konceptu vychovávat' mužov, ktorí by boli „[...] v reči slovenskej vedecky vyučení, národu slovenskému láskou oddaní a za advokátov, súdnych a politických úradníkov preň súci, ktorížto by takí úrad svoj medzi Slovákmi dla predpisu vysokého nařídenia práv a vnútra [...] náležite plnit’ mohli. ${ }^{194}$ Spolok a národné hnutie teda ašpirantov na právnické vzdelanie nepodporovali náhodne. V dôsledku značných spoločenských zmien si uvedomili, že pre národné hnutie budú v blízkej budúcnosti dôležitejší právnici než napríklad kňazi, ktorí v prvej polovici 19. storočia tvorili dominantnú zložku národného hnutia. ${ }^{95} \mathrm{~V}$ porovnaní s inými profesiami mali právnici podstatne jednoduchšiu možnost' politického uplatnenia. Z podporených študentov boli neskôr politicky aktívni viacerí a niektorí (Vendelín Kutlík, Matúš Dula a František Veselovský) viackrát kandidovali do uhorského snemu. Uspiet' sa však podarilo iba Františkovi Veselovskému v roku $1901 .^{96}$ Vyštudovaní právnici mohli rozvinút' aj vlastnú právnickú kariéru, založit’ právne kancelárie a v súdnych sporoch zastupovat’ iných príslušníkov národného hnutia. Čo sa aj uskutočnilo, ked’že slovenský nacionalizmus využíval ich nadobudnuté právne vzdelanie v súdnych sporoch,

87 Letopis Matice slovenskej, 1868, roč. 5, č. 1, s. 84.

88 Hurban, Svetozár (* 16. január 1847 - † 17. august 1916) bol synom evanjelického farára Jozefa Miloslava Hurbana. Právo vyštudoval v Bratislave, usadil sa v Turčianskom Sv. Martine a venoval sa predovšetkým krásnej literatúre a publicistike.

89 Hudec, Žigmund (*?-†?) právo študoval v Bratislave. Neskôr pravdepodobne pôsobil ako úradník v Balážskych Ďarmotách.

90 Mráz, František (*?- † 1871) právo vyštudoval vo Viedni a v Pešti. Následne sa usadil v Žiline a pôsobil tu ako notár, no zomrel mladý v roku 1871.

91 Porubský, Ján Karol (*22. marec 1846 - † 9. máj 1907) právo vyštudoval v Bratislave a následne sa usadil v Trenčíne, kde mal vlastnú advokátsku prax, pričom zastával pozíciu aj v mestskej rade Trenčína a v kancelárii vojenského dôstojníka.

92 Schuster (Šuster), Jozef. (*?- †?) študoval na gymnáziu v Banskej Bystrici a neskôr právo v Pešti. Odporúčanie na získanie štipendia dostal od Martina Čulena.

93 KOVÁČ 2015, s. 403.

94 BOKES, František. Dokumenty k slovenskému národnému hnutia v rokoch 1848 - 1914. Bratislava : Vydavatel'stvo Slovenskej akadémie vied, 1962, s. 188.

95 K tejto téme pozri viac: HUČKO 1974, s. 18-52.

96 SLÁVIK, Michal. Slovenskí národovci do 30. októbra 1918. Trenčín : Vojtech Čelko, 1945, s. 339-340. 
ktoré mali okrem právneho hladiska aj nacionálny podtext. Spomeňme Matúša Dulu, ktorý ako advokát viedol právny spor za obnovenie zrušeného gymnázia v Turčianskom Sv. Martine a v roku 1906 obhajoval Vavra Šrobára v známom ružomberskom procese. ${ }^{97} \mathrm{~V}$ podobných intenciách rozvinuli svoju kariéru aj iní podporení študenti a založili si vlastné právnické kancelárie (Ján Karol Porubský, Ambro Pietor, František Veselovský, Samuel Medvecký, Miroslav Kulíšek, Peter Krno, Cyril Hodža, Peter Jamnický, Žigmund Melfelberg, Milan Trokan, Vendelín Kutlík a Jozef Kohút). Právnici mohli pôsobit' aj v štátnej a verejnej správe, zastávat’ úradnícky post či už na župnej, alebo štátnej úrovni. Samotná štátna moc Uhorska bola postavená na úradníckom aparáte. Úradníci tiež patrili popri armáde a cirkvi k trojici tradičných opôr štátu a dynastie. 0 úradnícky post bol neustály záujem, ktorý podporovala aj primeraná vážnost' úradníka v spoločnosti. Aj napriek postupnej premene uhorskej stavovskej spoločnosti na občiansku, ked' sa úradnícke funkcie stali dostupnejšie širším vrstvám spoločnosti, zostávali najvyššie posty stále vyhradené pre l'udí so šlachtickými titulmi a tomu primeraným majetkovým zázemím. ${ }^{98} \mathrm{~V}$ poslednej tretine 19. storočia úradnícku pozíciu s pomedzi spolkových štipendistov na istý čas zastávali Ján Karol Porubský, Žigmund Hudec, František Mráz, Anton Pavel Bulla a Baltazár Tomka. V štátnej správe mohli právnici pôsobit’ aj ako sudcovia, čo sa z podporených študentov podarilo Emilovi Zacharovi a Jozefovi Strakovičovi. Prvý menovaný v tejto sfére zaznamenal značný kariérny postup a stal sa predsedom senátu Uhorskej královskej kúrie v Budapešti, z čoho môžeme usudzovat', že prestal byt' lojálny voči slovenskému národnému hnutiu.

Matiční štipendisti sa po štúdiách odborne aj spoločensky etablovali a presadili. Avšak nakol'ko bola z pohladu národného hnutia a spolku podpora na nich vynaložená výhodná? Vo väčšine prípadov sa investície v podobe vzdelaných a stotožnených jednotlivcov s ideami národného hnutia naplnili. Aj pre spolok to bolo v určitých, síce iba zriedkavých prípadoch výhodnou investíciou. Pretože niektorí štipendisti sa sami (alebo ich deti v 20. storočí) stali nielen členmi Matice, ale dostali sa aj do výboru. Aktívne sa podiel’ali na fungovaní inštitúcie a pokračovali v napíňaní ideí národného hnutia. Výhodou pre spolok boli študenti (pätina z podporených), ktorí už ako členovia spolku zaplatili členský poplatok. Tak sa vrátila Matici aj čast' investovaných peňazí. Spolkovými výborníkmi z bývalých štipendistov, o ktorých máme záznamy, sa stali: Žigmund Melferber, Ambro Pietor a Jozef Kohút. Avšak títo traja žili a pôsobili práve v sídle spolku, čo možno pokladat' za jeden z hlavných dôvodov, prečo sa do výboru dostali. Spolok sa centralizoval do Turčianskej župy a do výboru boli vyberaní práve tí, ktorí tam žili a pôsobili. Na vrcholnú pozíciu v spolku sa po roku 1918 dostal Matúš Dula. Ako 72-ročný bol jedným z piatich predsedov spolku, aj ked' ten už fungoval podla iných stanov a pravidiel. Post predsedu bol v tomto období výsostne čestnou funkciou.

Možno teda konštatovat', že čiastočne bolo aj z pohl'adu národného hnutia udelovanie štipendií výhodnou investíciou. Niektorí z podporených študentov sa po skončení štúdií stali aktívnymi protagonistami v komunite národovcov a zaradili sa medzi národovecké elity. Nedokážeme presne identifikovat', do akej miery sa tí-ktorí úplne stotožnili s ideami slovenského nacionalizmu.

97 HOLEC, Roman. Tragédia v Černovej a slovenská spoločnost'. Martin : Matica slovenská, 1997, s. 93-94.

98 HOLEC 2004, s. 42. 
Podla dostupných zistení tu možno zaradit’ týchto šestnástich: Miloslav Kulišek, Svetozár Hurban, Matúš Dula, Ambro Pietor, František Veselovský, Samuel Medvecký, Cyril Hodža, Peter Jamnický, Žigmund Melferber, Samuel Zachej, Milan Trokan, Jozef Strakovič, Karol Porubský, Vendelín Kutlík, Jozef Kohút a Baltazár Tomka.

V prípade Emila Zachara, ktorý získal významnú pozíciu v uhorskom súdnictve, možno jednoznačne povedat', že sa stotožnil s ideami uhorsko-mad’arského národného hnutia.

U d’alších študentov - Žigmund Hudec, František Mráz, Anton Pavel Bulla a Baltazár Tomka sa nedá jednoznačne povedat', či sa stotožnili s ideami slovenského národného hnutia, a teda nakol'ko bola investícia do nich z pohladu spolku výhodnou, respektíve nevýhodnou.

Dôležité i zaujímavé je vediet’, z akých sociálnoekonomických vrstiev štipendisti vzišli. Avšak nie pri každom z nich bolo možné identifikovat’ sociálny pôvod. Podarilo sa to pri trinástich, čo predstavuje $52 \%$. Deviati pochádzali z rodín inteligencie, teda z rodiny evanjelického a.v. farára, dedinského učitela a notára. Štyria štipendisti vyšli z plebejských rodín. Títo štyria, menovite Bulla, Dula, Pietor, Strakovič dokázali svoj potenciál rozvinút' a etablovat’ sa v nových spoločenských vrstvách. Jozef Strakovič sa usadil v Pešti, kde pôsobil ako praktikant v Uhorskej král'ovskej tabuli. Neskôr mal v hlavnom meste Uhorska vlastnú advokátsku kanceláriu. Matúš Dula a Ambro Pietor sa usadili v Turčianskom Sv. Martine, pričom obaja mali istý čas advokátsku firmu. Druhý z nich neskôr pôsobil ako redaktor Národných novín a vydavatel'. Anton Pavel Bulla sa presadil ako štátny úradník pôsobiaci v Dolnom Kubíne, no nádejnú kariéru mladíka prekazila smrt'. Ako vidiet' na príklade Dulu, Bullu, Pietra a Strakoviča uhorské pomery v poslednej tretine 19. storočia, premena stavovskej spoločnosti na občiansku umožňovali sociálny vzrast aj l'ud’om plebejského pôvodu.

V tomto období sa v prostredí Horného Uhorska vyformovalo niekol'ko generácií právnických i podnikatel'ských rodín, ktoré boli aktívne aj v slovenskom národnom hnutí. V meste a regióne, kde žili a pôsobili, zohrávali významnú úlohu predovšetkým ako mestské elity, neraz aj ako mecéni kultúrnych a politických aktivít. ${ }^{99}$ Podobne to bolo aj s podporenými študentmi. Tí už ako otcovia svojim synom umožnili nadobudnút' vzdelanie, a to predovšetkým také, aké sami dosiahli. $\mathrm{V}$ niekol'kých prípadoch sa stali zakladatel'mi viacgeneračných rodín právnikov. Išlo predovšetkým o rodiny Dulovcov (syn Ján právnik), Jamnických (syn Otakar právnik), Medveckých (syn Ludovít právnik), Zacharovcov (syn Július právnik), Pietrovcov (synovia Miloš a Igor i vnuk Ivan právnici) a Kutlíkovcov (syn Vladimír právnik). Dokonca niektorí z podporených študentov (napr. Medvecký, Dula a Pietor) sa už ako zrelí muži dokázali presadit’ aj v rozmáhajúcom sa finančníctve a stali sa bud' zakladatel'mi, alebo členmi dozorných rád bánk, čo posilnilo ich právomoci a, pravdaže, zlepšilo ich finančné zabezpečenie.

Matičné štipendiá dopomohli mladým študentom doštudovat' a rozbehnút' kariéru, čo následne viedlo k zvýšeniu ich spoločenského i ekonomického postavenia. Väčšinou sa presadili v regiónoch a mestách s prevahou slovenského obyvatel'stva. Išlo o lokality s nižším počtom

99 HOLEC, Osobnost' a región, s. 46. 
obyvatel'ov, a teda aj s nižšou konkurenciou, čo ul'ahčovalo proces ich sociálneho vzostupu. Malé mestá a malost’ slovenského nacionalizmu, na čo poukázal Roman Holec, mali za následok značné rodinné prepojenie slovenských národovcov. Príkladom môžu byt' mestá ako Turčiansky Sv. Martin i Liptovský Sv. Mikuláš, kde sa pracovné miesta v slovenských priemyselných podnikoch vo vel’kej miere obsadzovali rodinnými príslušníkmi v zmysle „kreslo otca bolo najvhodnejšie pre syna. “100 Do akej miery boli rodinnými väzbami prepojené aj viacgeneračné rodiny slovenských právnikov v 19. storočí, nie je dnes ešte celkom jasné.

\section{Záver}

Spolok, no predovšetkým jeho vedenie možno považovat' za združenie, v ktorom sa zoskupovali a etablovali elitné vrstvy slovenskej, národne uvedomelej a angažujúcej sa spoločnosti. Nie každý, kto by sa v ňom chcel aktívne angažovat', si mohol dovolit' zaplatit' členský poplatok a aktívne sa zúčastňovat’ na valných a výborových zasadnutiach. Aj pri pohlade na členskú základňu spolku vidíme, že išlo o vzdelanecké vrstvy spoločnosti, ktorých sociálnoekonomické zaradenie im umožnilo doň vstúpit'. V prípade l'udí zastúpených vo výbore spolku v počiatočných rokoch môžeme povedat', že išlo o osoby celouhorského významu. V d’alších rokoch výbor spolku tvorili osoby, ktoré môžeme označit’ za regionálne či mestské elity.

Nie je možné jednoznačne povedat', nakol'ko boli všetci členovia spolku stotožnení s ideami slovenského národného hnutia. Ani o osobnostiach angažujúcich sa v spolku nemožno jednoznačne a zovšeobecňujúco tvrdit', že išlo o slovenské národovecké elity. Niektorí vnímali Uhorsko ako multietnický štát, iní sa stotožnili s politikou presadzovanou uhorskými/mad’arskými elitami, ktoré spájali sociálne, ekonomické i politické reformy predovšetkým s jazykovou homogenizáciou Uhorska a vstúpili do služieb uhorských/mad’arských nacionálnych kruhov. V tomto prostredí sa dokázali odborne, politicky i spoločensky presadit'. Ide napríklad o Emila Zachara, ktorý ako matičný štipendista urobil strmú kariéru v uhorskej justícii. Platí to aj o členoch výboru, napríklad Bedřich Baltík sa stal evanjelickým a. v. biskupom predunajského dištriktu, a d'alší člen spolku, Arnold Ipolyi Stummer, biskupom banskobystrickej a neskôr vel'kovaradínskej diecézy.

Vynaložené finančné prostriedky, predovšetkým štipendium v najvyššej výške 125 zlatých, podstatne ulahčili život a štúdium mladých mužov, no automaticky nezaručovali, že sa z mladého študenta stane príslušník elitnej vrstvy spoločnosti, ani že sa zaradí medzi národovecké elity. Druhú najvyššiu sumu peňazí spolok vyplatil Jánovi Cebecauerovi, no ten aj napriek tomu, že sa ako mladý formoval v silne národoveckom banskobystrickom prostredí, sa neskôr v Hornom Uhorsku nedokázal uplatnit' a odišiel do Sedmohradska. Z dial'ky sa nedokázal výrazne angažovat' $v$ národnom hnutí. Z podporených študentov sa medzi národovecké elity dotiahli predovšetkým Matúš Dula, ktorý sa stal predsedom Slovenskej národnej strany, a Svetozár Hurban, z ktorého sa stala popredná osobnost’ v martinských kruhoch i plodný spisovatel'. Dvaja (Dula a Melfelber) sa dožili vzniku Československej republiky, pričom prvý vymenovaný sa stal aj signatárom Martinskej deklarácie.

100 HOLEC, Osobnost' a región, s. 47. 
V štúdii som sa pokúsil identifikovat’ základné prostriedky, ktoré využíval slovenský nacionalizmus v 60. rokoch 19. storočia na utváranie a reprodukovanie nových národoveckých elít. Snažil som sa identifikovat’ základné faktory umožňujúce sociálny vzostup neelitného obyvatel'stva do radov elít a zotrvanie v tejto pozícii. V sledovanom období to bolo predovšetkým získanie vyššieho vzdelania. Slovenský nacionalizmus to podporoval formou pridelenia štipendií vybraným jednotlivcov, ktorí formou odporúčaní starších národovcov dokazovali svoju lojalitu národnému hnutiu. Národné hnutie cielavedome podporovalo študentov práva, ktorým práve tento odbor následne umožnil rozvoj vlastnej právnej praxe i možnost' zastávania úradov, získanie finančného i sociálneho kapitálu a následne investovanie tohto kapitálu do d’alších podnikov, ako napr. vznik bankového domu a taktiež vznik viacgeneračných právnických rodín. Predkladaná štúdia je len čiastkovým pokusom o bližšie poznanie národných elít v 60. rokoch 19. storočia a ich sociálneho zloženia a pôvodu. Niektoré tvrdenia v štúdii majú z hladiska doterajšieho bádania platnost' pracovných hypotéz, ktoré bude potrebné d’alším výskumom overit', potvrdit' či revidovat'.

Cituj:

MOLDA, Rastislav: Stratégia vytvárania národoveckých elít v najznámejšom slovenskom spolku. In Forum Historiae, 2018, r. 12, č. 1, s. 44-65. ISSN 1337-6861.

$\cdots$

Mgr. Rastislav Molda, PhD.

Stredoslovenské múzeum

Nám. SNP 3755/4A

97401 Banská Bystrica

molda@ssmuzeum.sk 